http://dx.doi.org/10.12775/szhf.2020.008

JoANna ZegZuŁa-NowaK

UNIWERSYTET ZiELONOGÓRSKI

E-MAIL: JOANNA_ZEGZULA@VP.PL

ORCID: 0000-0003-4280-849X

\title{
Mieczysław Wallis a/i Maria Ossowska. Studium relacji na marginesie materiałów archiwalnych
}

Mieczysław Wallis to uczony, który mimo niezwykle bogatego i cechującego się ogromną różnorodnością i wnikliwością rozważań dorobku twórczego $^{1}$ jest postacią wciąż mało znaną w rodzimej humanistyce XX wieku. Dotychczasowe opracowania jego sylwetki twórczej nie oddają bogactwa jego zainteresowań naukowych i nie ukazują w pełni intelektualnych inspiracji, którym ulegał². Jako człowiek nauki utożsamiany jest przede wszystkim z estetyką, historią i teorią sztuki oraz krytyką literacką. To jednak zawężony i uproszczony obraz tej osoby. Wallis pozostawił bowiem po sobie niezwykle

1 Wśród jego dzieł znajduje się około dziewięciuset pozycji: książek, artykułów, recenzji, tłumaczeń, opracowań. Por. Krzysztof Rutkowski, „Bibliografia prac Mieczysława Wallisa”, w: Sylwetki łódzkich uczonych. Profesor Mieczysław Wallis, z. 59 (Łódź: Łódzkie Towarzystwo Naukowe, 2001), 19-60.

2 Por. Teresa Pękala, Estetyka otwarta Mieczysława Wallisa (Warszawa: Instytut Kultury, 1997), 1-204 oraz tejże, „Świat jako przedmiot estetyczny. Wprowadzenie”, w: Mieczysław Wallis, Wybór pism estetycznych (Kraków: Universitas, 2004), X-CXIV. 
rozległą - obejmującą kilkanaście tysięcy kart - spuściznę archiwalną̧ ${ }^{3}$ jednak wiele jego prac nie zostało dotąd opracowanych i opublikowanych. Wartość naukowa tych materiałów, stanowiących efekt jego wieloletnich przemyśleń, doświadczeń oraz dyskusji i polemik prowadzonych z ówczesnymi intelektualistami, wydaje się dla polskiej humanistyki nieoceniona. Zapewne jednak dopiero ich dokładna analiza pozwoli na głębsze poznanie, zrozumienie i właściwe ujęcie drogi jego naukowego rozwoju, a także zainteresowań twórczych i doniosłości jego intelektualnych dokonań.

Co ważne, Wallisowskie zapiski oraz gromadzone przezeń materiały (przede wszystkim wycinki prasowe, prace i wypowiedzi innych myślicieli, listy oraz zdjęcia) wskazują, że na kształt jego sylwetki twórczej w sposób istotny wpłynęły postawy i poglądy wielu wybitnych, rodzimych intelektualistów XX wieku. Lista osób - głównie uczonych i artystów istotnych dla zbiorów archiwalnych Wallisa - zawiera kilkadziesiąt nazwisk. Tymczasem materiały na ich temat obejmują prace o różnej objętości. O niektórych uczonych pojawiają się notatki sporadyczne, czasem wręcz akcydentalne, tymczasem innym postaciom Wallis poświęca głębszy namysł, wspomina je z większą uwagą. Stąd też i ich wpływ na poglądy autora dzieła Przeżycie i wartość był zapewne różny. Spośród tych, których Wallis szczególnie cenił, których postawami intelektualnymi się inspirował i z którymi niejednokrotnie dzielił sukcesy i trudy życia akademicko-naukowego, często prowadząc ożywioną wymianę myśli, należy wymienić przede wszystkim Henryka Elzenberga, Tadeusza Kotarbińskiego oraz Jana Łukasiewicza ${ }^{4}$.

3 Materiały archiwalne M. Wallisa znajdują się w zbiorach Połączonych Bibliotek Wydziału Filozofii i Socjologii UW, Instytutu Filozofii i Socjologii PAN oraz Polskiego Towarzystwa Filozoficznego w Warszawie, gdzie po śmierci uczonego przekazała je jego synowa - Elżbieta Grabska-Wallis (katalog rękopisów PTF 04-38). Niewielka część archiwaliów uczonego znajduje się także w Zbiorach Specjalnych Instytutu Sztuki Polskiej Akademii Nauk. Zob. Instytut Sztuki Polskiej Akademii Nauk, Zbiory specjalne, http://www.ispan.pl/pl/zbiory/zbiory-specjalne, dostęp: 26.01.2020.

4 Por. Mieczysław Wallis, Materiały Archiwalne, katalog rękopisów PTF 04-38, teczki poświęcone: Henrykowi Elzenbergowi - Rps 15, t. I, Rps 16, t. I-III; Tadeuszowi Kotarbińskiemu - Rps 14, t. I-IV; Janowi Łukasiewiczowi - Rps 8, Rps, 10, T. I, VI, IX. Wyniki prac prowadzonych przeze mnie w zakresie relacji Wallisa $\mathrm{z}$ tymi uczonymi znajdują się w następujących publikacjach: „Jan Łukasiewicz jako nauczyciel, mentor i inspirator twórczej aktywności Mieczysława Wallisa”, Studia z Historii Filozofii 2 (2018): 69-90; „Henryk Elzenberg w świetle nieznanych źródeł archiwalnych Mieczysława Wallisa”, Studia z Historii Filozofii 
Co ciekawe, w Wallisowskich wspomnieniach widnieją także sylwetki wybitnych postaci rodzimej humanistyki XX wieku, których wpływ na rozwój intelektualny Wallisa wydaje się niejednoznaczny, choć z różnych względów (np. powszechnie znanych powiązań biograficznych i naukowych) może okazać się istotny. Do tego właśnie grona należała Maria Ossowska.

Archiwalia zawierające Wallisowskie reminiscencje poświęcone tej uczonej zostały zdeponowane w teczce o numerze Rps 11 i obejmują dwa pierwsze tomy ${ }^{5}$. Mimo iż zawierają zaledwie trzydzieści cztery karty, to niewątpliwie stanowią cenną kopalnię wiedzy historyczno-filozoficznej. Odzwierciedlają bowiem swoistość relacji łączącej tych uczonych. Ukazują jej subtelny, nie nachalny, acz pełen wzajemnego uznania i koleżeńskiej sympatii charakter, opowiadają o wspólnych doświadczeniach z życia akademickiego i uwidaczniają konstytuujące się już wówczas, wspólne dla obojga rysy postaw naukowych oraz wartości, które oboje cenili.

Warto podkreślić, że ich zawartość stanowi także ważny trop badawczy, pozwalający słusznie zakładać istnienie wielu nieznanych jeszcze bądź niedostatecznie docenianych i eksponowanych analogii oraz powiązań między nimi. Historia rodzimej humanistyki pokazuje, że cenne i inspirujące relacje nie zawsze muszą mieć charakter oczywisty, powszechny, pierwszoplanowy. Nić porozumienia może bowiem połączyć ludzi o pozornie odmiennych intelektualnych inklinacjach, a do tego często pozostających w przestrzennym oddaleniu. Fundamentem pomostu intelektualnego pomiędzy ludźmi mogą być nie tylko bezpośrednie ogniwa naukowej współpracy, ale także wspólne autorytety, idee i podstawy aksjologiczne, którymi przesiąkali, dojrzewając naukowo, i które w sobie ugruntowali. Podążając zatem szlakiem Wallisowskich materiałów archiwalnych oraz biografii naukowych obojga uczonych, warto przyjrzeć się ich sylwetkom twórczym, szczególny nacisk kładąc na

2 (2016): 137-153; Mieczysław Wallis i Henryk Elzenberg o sztuce i moralności (na podstawie korespondencji wzajemnej) (Zielona Góra: Oficyna Wydawnicza Uniwersytetu Zielonogórskiego, 2016); „Tadeusz Kotarbiński w świetle nieznanych źródeł archiwalnych Mieczysława Wallisa", w: Homo moralis - homo creativus. Prace dedykowane profesorom Zdzisławowi Kalicie, Krzysztofowi Kaszyńskiemu, red. Joanna Dudek i in. (Zielona Góra: Oficyna Wydawnicza Uniwersytetu Zielonogórskiego, 2015), 209-230; „Mieczysław Wallis i Henryk Elzenberg w estetyce polskiej XX wieku. Studium porównawcze”, Edukacja Filozoficzna 55 (2013): 61-80.

${ }^{5}$ III tom tejże teczki zawiera archiwalia poświęcone Stanisławowi Ossowskiemu. 
ich możliwe wzajemne powiązania (doświadczenia, relacje ze środowiskiem intelektualnym, dyrektywy naukowe). Mogą one bowiem stanowić filar towarzyszącego im przez większość życia poczucia przynależności intelektualnej, jak też jeden z czynników decydujących o trwałości ich indywidualnej duchowej więzi.

\section{Materiały archiwalne Mieczysława Wallisa jako źródło wiedzy o jego relacji z Marią Ossowską. Charakterystyka ogólna}

Wallisowskie archiwalia poświęcone Marii Ossowskiej stanowią unikatowe i nieznane szerszemu gronu swoiste reminiscencje dotyczące zarówno osobowości twórczej autorki Podstaw nauki o moralności, jak i łączącej ją z Wallisem relacji koleżeńsko-naukowej. Prezentują także (choć nie zawsze wprost) wiele istotnych powinowactw intelektualnych występujących pomiędzy nimi, wyrosłych nie tyle ze wspólnych doświadczeń życiowych, co przede wszystkim z posiadania tych samych wartości i dyrektyw naukowych.

Wallisowskie materiały dotyczą wydarzeń obejmujących półwiecze ich życia. Ich kres wyznacza moment śmierci Ossowskiej w 1974 roku. Tom pierwszy prezentowanych archiwaliów zawiera wspomnienia poświęcone przede wszystkim najwcześniejszemu okresowi ich znajomości, kiedy to relacja Wallisa i Ossowskiej dopiero się krystalizowała. Zapiski skupione są zatem przede wszystkim na ich wczesnej młodości (lata 1916-1921), a do dalszych etapów ich życia odnoszą się już bardziej wyrywkowo. Zapewne nieprzypadkowo to temu okresowi ich znajomości Wallis poświęcił najwięcej uwagi. Wówczas to bowiem przyszły uczony miał największą sposobność częstego przebywania z Ossowską (jako że należeli do jednego środowiska studenckiego) i zarazem pogłębiania swej relacji z nią, zarówno na niwie intelektualnej, jak i koleżeńskiej. Stąd też zapewne właśnie ten etap jawił się Wallisowi jako najistotniejszy, najbardziej konstytutywny w ich stosunkach i dlatego był godny upamiętnienia. Warto jednak zaznaczyć, że związki intelektualne z czasów wczesnej młodości, którym Wallis poświęcił główny trzon swych wspomnień, mimo 
braku wielu odniesień w archiwaliach dość wyraźnie zarysowują się także w okresie dojrzałej aktywności naukowej Wallisa i Ossowskiej. Uwidoczniają się one przede wszystkim w zbieżnościach co do sposobu rozumienia i uprawiania nauki, postawach metodologicznych, warsztacie pracy, a także specyfice aktywności w środowisku naukowo-zawodowym.

Należy też podkreślić, że choć omawiane wspomnienia sięgają czasem wydarzeń rozgrywających się nawet kilkadziesiąt lat wstecz, to są one każdorazowo niezwykle żywe, plastyczne i dokładne - zawierają wiele szczegółowych informacji i detali. Jest to istotna cecha całej twórczości Wallisa, niezwykle dbającego o styl i precyzję wyrazu głoszonych treści, będąca zarazem znaczącym rysem jego pisarskiego kunsztu.

Z kolei tom drugi stanowi swoisty zapis intelektualnej drogi Marii Ossowskiej, za którą podążał Wallis, śledząc jej dokonania naukowe poprzez gromadzenie poświęconych jej wycinków prasowych. Znajdują się tu zatem adnotacje z jej jubileuszów pracy naukowej, wywiady z uczoną, wspomnienia pośmiertne osób z jej bliskiego otoczenia naukowego, a także jej nekrolog.

$\mathrm{Na}$ kartach swego dziennika uczony przybliżył istotę relacji towarzyskiej łączącej go z Ossowską, osadzając ją w ówczesnych realiach akademickich, a ponadto szczegółowo opisał wygląd, osobowość, charakter oraz zainteresowania i intelektualne przymioty autorki Podstaw nauki o moralności. Archiwalia te stwarzają zatem niepowtarzalną okazję, by oczami ich autora spojrzeć na uczoną na różnych etapach jej życia i rozwoju intelektualnego (od czasów studenckich po późny wiek dojrzały), poznać ją jako uczoną i wykładowczynię oraz podjąć próbę określenia jej wpływu na postawę intelektualną Wallisa.

Co ważne, ze względu na dość szeroki kontekst ujęcia sylwetki twórczej Marii Ossowskiej (zarówno jeśli chodzi o zakres czasowy, jak i bogactwo wątków) wspomnienia te to nie tylko istotne źródło wiedzy o samej filozofce, ale także swoista egzemplifikacja życia i prowadzenia pracy naukowej rodzimych intelektualistów tego okresu, jak również niezwykle cenne świadectwo epoki, w której prezentowani uczeni żyli i tworzyli. Stąd też analiza opisywanych materiałów może stanowić intelektualną ucztę dla miłośników spuścizny Mieczysława Wallisa i Marii Ossowskiej oraz dla wszystkich osób zainteresowanych odkrywaniem mało znanych czy też nieoczywistych kart historii rodzimej humanistyki. 


\section{Maria Ossowska w humanistyce polskiej XX wieku}

Maria Ossowska to uczona, której umysłowość i dokonania intelektualne znacząco wpłynęły na oblicze rodzimej humanistyki, przede wszystkim w dziedzinie etyki i badań nad moralnością. Zarówno rozległość prowadzonych przez nią prac naukowo-badawczych, jak i znaczenie podejmowanych zagadnień zapewniły uczonej stałe miejsce wśród najwybitniejszych polskich intelektualistów XX wieku. Jak przekonują badacze jej twórczości:

Wszechstronność dorobku Ossowskiej właściwie uniemożliwia tym, którzy w sposób odpowiedzialny uprawiają etykę, pozostać obojętnym na problemy, metody, wskazówki w nim zawarte. [...]. Twórczość uczonej stanowi jednocześnie wyzwanie dla badaczy, którzy wybierają odrębną drogę w uprawianiu etyki. Zapewne [...] odpowiedź na postulaty badawcze i etyczne Ossowskiej to przejaw walki z nałogami myślowymi, zastanymi schematami i stereotypami, to wyraz odwagi intelektualnej i moralnej człowieka ${ }^{6}$.

Warto zaznaczyć, że wiele intelektualnych dociekań uczonej miało charakter ponadczasowy i było ważnym obszarem refleksji oraz inspiracji dla współczesnego człowieka. Nie bez powodu zatem sylwetka intelektualna Ossowskiej od dziesięcioleci stanowi przedmiot wielu prac badawczych i przedsięwzięć naukowych podejmowanych najpierw przez osoby blisko z nią współpracujące i ceniące ją naukowo (uczniów, współpracowników, nauczycieli akademickich $)^{7}$, a następnie przez badaczy i zwolenników jej koncepcji oraz rozstrzygnięć naukowych: socjologów, pedagogów, kulturoznawców, etnologów, historyków filozofii, ale przede wszystkim etyków i aksjologów zgłębiających dzieje rodzimej refleksji moralnej i poszukujących nie tylko inspiracji twórczych, ale także trwałych fundamentów w wytyczaniu uniwersalnych dla ludzkości dyrektyw, zarówno intelektualnych, jak i życiowych. Stąd też bogactwo źródeł dotyczące dorobku uczonej stale się po-

6 Joanna Dudek, „Wstęp”, w: W kręgu twórczości Marii Ossowskiej: analiza - inspiracje alternatywy, red. tejże i in. (Zielona Góra: Oficyna Wydawnicza Uniwersytetu Zielonogórskiego, 2018), 7-8.

7 Por. np. Intymny portret uczonych. Korespondencja Marii i Stanisława Ossowskich (Warszawa: Sic, 2002). 
większa, także o opracowania jej spuścizny archiwalnej. Twórczość uczonej nadal bywa przedmiotem licznych monografii (pisanych zarówno w ramach przedsięwzięć indywidualnych autorów, jak i dzieł zbiorowych), artykułów, wystąpień, odczytów czy konferencji naukowych. Na przestrzeni kilkunastu ostatnich lat powstało co najmniej kilkanaście prac na jej temat (w tym rozpraw habilitacyjnych, doktorskich oraz monografii zbiorowych i artykułów). Ku jej pamięci odbyło się także kilka konferencji naukowych o zasięgu krajowym ${ }^{9}$.

Tym samym każde nowe źródło wiedzy o autorce Podstaw nauki o moralności ukazujące ją jako uczoną lub człowieka zakorzenionego w określonej rzeczywistości społecznej, historycznej lub akademickiej warte jest uwagi, analizy i refleksji. Daje bowiem sposobność dopełnienia wiedzy o uczonej lub też ukazania jej twórczości w innej niż dotychczasowa perspektywie. Szczególnie zaś unikatowe i cenne źródło wiedzy mogą stanowić nieopracowane jeszcze zbiory archiwalne - zarówno samej uczonej, jak też twórców takich jak Mieczysław Wallis, będących reprezentantami jej intelektualnego otoczenia, z którymi bezpośrednio krzyżowały się jej losy.

8 Por. np. Maria Ossowska (1896-1974) w świetle nieznanych źródeł archiwalnych, red. Joanna Dudek i in. (Zielona Góra: Oficyna Wydawnicza Uniwersytetu Zielonogórskiego, 2011).

9 Por. Nauka Polska, wyszukiwanie dla hasła „Maria Ossowska”, https://nauka-polska.pl, dostęp: 26.01.2020, oraz „Maria Ossowska 1896-1974”, http://ossowska.isns.uw.edu.pl/publikacje.html, dostęp: 26.01.2020. Warto wymienić tu np. takie publikacje, jak: Maria Ossowska - człowiek i badacz moralności z 2006 roku, autorstwa Krzysztofa Kicińskiego; Maria Ossowska a inni badacze polscy, autorstwa Krzysztofa Sztalta, również z tego roku; Maria Ossowska: intelektualista - po prostu, autorstwa Wojciecha Pawlika, także z 2006 roku; pracę habilitacyjną Joanny Dudek: Problem unaukowienia etyki z 2012 roku; oraz prace doktorskie: Anety Jakubik pt. Aksjologiczne podstawy nauki o moralności Marii Ossowskiej i Tomasza Dąbrowskiego pt. Nauka o moralności w Polsce od Juliana Ochorowicza do Marii Ossowskiej z 2009 roku. Jednym z ostatnich przedsięwzięć poświęconych dorobkowi naukowemu Marii Ossowskiej, skupiających środowisko rodzimych etyków, była Ogólnopolska Konferencja Naukowa z cyklu MORALNOŚĆ - WSPÓŁDZIAŁANIE - NIEZALEŻNość: W kręgu twórczości Marii Ossowskiej: analiza - inspiracje - alternatywy, która odbyła się 8-9 września 2016 roku w Instytucie Filozofii (Zakład Etyki) Uniwersytetu Zielonogórskiego. 


\section{Maria Ossowska w świetle rękopiśmiennych wspomnień Mieczysława Wallisa}

Maria Ossowska i Mieczysław Wallis należeli do jednego pokolenia intelektualnego. Ich ścieżki życiowe skrzyżowały się po raz pierwszy w okresie, kiedy stawiali pierwsze kroki w świecie nauki. Przyszli uczeni poznali się bowiem w czasach studenckich. Tuż po I wojnie światowej oboje wstąpili na nowo wskrzeszony Uniwersytet Warszawski, gdzie w latach 1916-1921 studiowali w ramach jednego rocznika akademickiego ${ }^{10}$. Co ważne, okres ten okazał się kluczowy dla całej ich późniejszej relacji.

W swych wspomnieniach opatrzonych nagłówkiem „Maria Niedźwiecka-Ossowska” Wallis pisał następująco o okolicznościach, w których nawiązał znajomość z przyszłą filozofką:

Marię Ossowską, podówczas jeszcze pannę Niedźwiecką, wysoką, smukłą, o hebanowo czarnych włosach i ciemnoniebieskich oczach, poznałem na początku 1916 r. Studiowaliśmy ten sam przedmiot - filozofię - na Uniwersytecie Warszawskim [...]. Start nasz był niemal jednakowy: Niedźwiecka miała za sobą rok studiów we Wszechnicy Jagiellońskiej, ja rok studiów na uniwersytecie w Heidelbergu. [...] Chodziliśmy na te same wykłady, byliśmy uczestnikami tych samych seminariów - profesorów Jana Łukasiewicza i Władysława Tatarkiewicza ${ }^{11}$.

Ich ścieżki życiowe przecinały się jednak nie tylko w murach akademickich, ale już w trakcie samej drogi na uczelnię. Wallis wspominał bowiem, co następuje:

Codziennie, nieraz nawet dwa razy dziennie, chodziliśmy, a raczej jeździliśmy tramwajem „osiemnastką" zwanym przez nas z francuska dyzjentką ${ }^{12}$, którego trasa wiodła Marszałkowską, Alejami Jerozolimskimi, Nowym Światem

${ }_{10}$ Okres akademickiej edukacji uczonych był niewątpliwie czasem ich najbliższej relacji koleżeńskiej oraz naukowej. Uczęszczając na te same zajęcia, nie raz mieli sposobność konfrontowania swych stanowisk i poglądów dotyczących zagadnień i problemów filozoficznych.

11 Wallis, Materiały Archiwalne, Rps 11, t. I, 120.

12 Z języka francuskiego: dix-huitième- „osiemnastka”. 
i Krakowskim Przedmieściem, do uniwersytetu, uczęszczaliśmy na te same wykłady i braliśmy udział w tych samych seminariach ${ }^{13}$.

To, że przyszli uczeni razem przemierzali drogę na zajęcia uniwersyteckie, nie było przypadkowe, gdyż mieszkali wówczas w bliskim sąsiedztwie. Wallis miał wtedy możliwość poznania bliżej Ossowskiej, zaznajomienia się z jej życiem codziennym, osobowością i sposobem bycia. Goszcząc zaś w jej rodzinnym mieszkaniu, poznawał także jej bliskich, ich zwyczaje i zainteresowania. Jak wspominał w swych zapiskach po latach:

Traf zdarzył, że moja najbliższa koleżanka, Maria Niedźwiecka (późniejsza Ossowska), mieszkała w tym samym domu przy ulicy Pięknej 62, co ja (mieszkałem u wujostwa na II piętrze, państwo Niedźwieccy mieszkali na III piętrze nad nami; dom był muzykalny, w niedzielę zwykle muzykowano i tańczono ${ }^{14}$.

Kolejną sposobność częstego obcowania ze sobą i w konsekwencji pogłębiania swej relacji na gruncie towarzyskim i naukowym dawały przyszłym uczonym także wspólne inicjatywy środowiska studenckiego, nie tylko wystąpienia i dyskusje na seminariach Jana Łukasiewicza, ale przede wszystkim członkostwo w Studenckim Kole Filozoficznym. Wallis miał wówczas możliwość poznać te zalety charakteru Ossowskiej, które okazały się fundamentalne dla jej przyszłej pracy badawczej i niewątpliwie ugruntowały jej naukowy sukces. Zapiski uczonego wskazują bowiem jednoznacznie, że już u progu aktywności naukowej u Ossowskiej kształtowała się postawa naukowej rzetelności i obowiązkowości. Reminiscencje dotyczące tej sfery jej osobowości intelektualnej Wallis opisał następująco:

Braliśmy żywy udział w działalności Koła Filozoficznego Studentów UW ${ }^{15}$. Po Stanisławie Krzywoszewskim i Stanisławie Ossowskim N.[iedźwiecka przyp. własny $]^{16}$ była Przewodniczącym tego Koła. Swe obowiązki członka Koła spełniała nader sumiennie. Do każdego posiedzenia przygotowywała się

13 Tamże, 118.

14 Tamże, 120.

15 Skrót dotyczy nazwy „Uniwersytet Warszawski”.

16 Skrót dotyczy nazwiska „Niedźwiecka”. Zob. także Maria i Stanisław Ossowscy. Intymny portret uczonych, 85-86, gdzie pod życzeniami dla ówczesnego Prezesa Koła Filozoficznego 
starannie, usiłując zapoznać się z tematem referatu, jaki miał być wygłoszony. W dyskusji zabierała głos rzadko, lecz zawsze w sposób starannie przemyślany ${ }^{17}$.

W innej notatce dotyczącej tego okresu wspominał:

Była ona już wtedy promiennym wzorem samodyscypliny, ładu, punktualności, systematyczności i metodyczności. Nie tylko do każdego posiedzenia seminarium, lecz do każdego zebrania Koła Filozoficznego przygotowywała się starannie, czytając prace związane z tematem, który miał być poruszony ${ }^{18}$.

Pracowitość i samozaparcie naukowe Ossowskiej stanowiły niewątpliwie cechy usposobienia, które Wallis niezwykle w niej cenił. Wspominał:

Podziwiałem zawsze jej niezwykłą siłę ducha, jej nieprawdopodobną dyscyplinę wewnętrzną. Gdy powiedziała sobie, że przeczyta taki a taki ustęp Leibniza, to zamiar ten wykonywała, chociażby była przepiękna pogoda i koledzy zapraszali ją na przechadzkę $e^{19}$.

Podkreślał też jej żarliwą ofiarność, determinację i wytrwałość w działaniach podejmowanych w słusznej sprawie. Pisał:

W sprawach światopoglądowych, moralnych lub politycznych cechowała ją rzadka bezkompromisowość. Zawsze była gotowa poświęcić wszystko dla sprawy, którą uważała za słuszną ${ }^{20}$.

Stąd zasadny wydaje się jego kolejny zapis, stanowiący swoiste podsumowanie postawy nie tylko naukowej, ale zapewne i życiowej uczonej, w którym pisał on, co następuje: „Gdybym miał zamknąć mój sąd o M.O. w jednym zdaniu, powiedziałbym: «Wszystko, co robiła, robiła wzorowo»"21.

Studentów Uniwersytetu Warszawskiego, opatrzonymi datą 1918 - S. Ossowskiego znajduje się lista ówczesnych jego członków.

17 Wallis, Materiały Archiwalne, Rps 11, t. I, 121.

18 Tamże, 118. Tekst opatrzony jest datą 27.VII.73.

19 Tamże, 122.

20 Tamże, 124.

21 Tamże, 126. 
We wspomnieniach autora dzieła Przeżycie $i$ wartość znajdują się także wzmianki dotyczące zainteresowań naukowo-badawczych Ossowskiej. Potwierdzają one wskazywaną wielokrotnie przez badaczy jej sylwetki twórczej ewolucję jej intelektualnych predylekcji oraz wyboru obszarów badawczych. W swych dociekaniach naukowych uczona przeszła bowiem od zainteresowań aksjologicznych do problematyki semantycznej, by ostatecznie skupić się na zagadnieniach z zakresu nauki o moralności (szczególnie rozważając kwestię jej naukowej autonomii) ${ }^{22}$. Wallis zaświadczał następująco:

Wcześnie poczęły ją interesować zagadnienia związane z sądami wartościującymi i wartościami. Pierwszy jej referat w Kole Filozoficznym był poświęcony rozprawie Durkheima Jugements de fait et jugements de valeur ${ }^{23}$. Jej rozprawa doktorska była poświęcona aksjologii stoików. Później głównym przedmiotem jej refleksji stały się najpierw zagadnienia semiotyczne (Stowa i myśli ${ }^{24}$, następnie moralność i możliwość jej naukowego uzasadnienia ${ }^{25}$.

Wizerunek uczonej, jaki sukcesywnie kreśli na kartach swych wspomnień autor dzieła Przeżycie $i$ wartość, to obraz niezwykle zaangażowanej, efektywnej badaczki, pełnej pasji i zapału do pracy twórczej. Szczere i niezwykle silne oddanie pracy naukowo-dydaktycznej Ossowskiej, któremu towarzyszyły stałe zabieganie o pogłębianie i szerzenie wiedzy oraz dbałość o własny rozwój intelektualny i duchowy, stanowiły zresztą jej naukową wizytówkę. Co istotne, podobne nastawienie można zaobserwować także w przypadku Wallisa. Jak podkreśla jego uczennica, Wanda Nowakowska, jego pełna entuzjazmu postawa naukowa wynikała $\mathrm{z}$ intelektualnej fascynacji i urzeczenia przedmiotem swych dociekań.

22 Por. Maria Ossowska, „Szkic autobiograficzny”, w: tejże, O człowieku, moralności i nauce. Miscellanea (Warszawa: PWN, 1983), 538-539. Szerzej o ewolucji zainteresowań naukowych Ossowskiej piszą: Joanna Dudek, Problem unaukowienia etyki. Teoretyczne i normatywne aspekty twórczości Marii Ossowskiej (Zielona Góra: Oficyna Wydawnicza Uniwersytetu Zielonogórskiego, 2012), 11-13 oraz Stefan Konstańczak, „Komentarz do wykładu habilitacyjnego Marii Ossowskiej”, w: Maria Ossowska (1896-1974) w świetle nieznanych źródeł, 43-67.

${ }^{23}$ Wystąpienie to dotyczyło zapewne rozprawy Durkheima pt. Jugements de valeur et jugements de réalité.

24 Rozprawa Słowa $i$ myśli stała się fundamentalną podstawą rozprawy habilitacyjnej Ossowskiej. Por. Maria Ossowska, „Słowa i myśli”, Przegląd Filozoficzny 4 (1931): 203-258.

25 Wallis, Materiały Archiwalne, Rps 11, t. I, 119. 
To właśnie urzeczenie prowadziło przez całe życie Profesora Wallisa do coraz głębszego zgłębiania wiedzy - nie tylko poprzez studiowanie książek naukowych, jak również arcydzieł literatury światowej ${ }^{26}$.

Maria Ossowska jako uczona i człowiek stale przykuwała uwagę Wallisa, czego dowodem są nie tylko jego własne rękopiśmienne wspomnienia, ale także fakt, że przez lata gromadził on wszystkie znalezione w prasie artykuły i noty jej poświęcone ${ }^{27}$. Wallis śledził aktywność Ossowskiej aż do ostatnich lat jej życia, niezmiennie ceniąc jej naukowy zapał, a także godność i spokój, z jakim znosiła ciosy od losu. Ich relację osłabiła z pewnością długotrwała choroba autorki Podstaw nauki o moralności, która stopniowo wyłączała ją $\mathrm{z}$ czynnego uczestnictwa $\mathrm{w}$ życia intelektualnym epoki ${ }^{28}$. Wallis pisał o tym następująco: „Ostatnie lata jej życia były okresem bohaterskiego zmagania się z chorobą. Gdy jeszcze tylko mogła, pracowała, np. nad przygotowaniem do druku dzienników jej męża”29.

Ostatnie ich spotkanie miało miejsce zaledwie kilka miesięcy przed śmiercią autorki Podstaw nauki o moralności. Wallis swe refleksje dotyczące tego wydarzenia opisał następująco: „Po raz ostatni widziałem Ossowską 22 marca 1974 r. ${ }^{30}$ na posiedzeniu Polskiego Towarzystwa Filozoficznego ku uczczeniu Władysława Witwickiego. Ciężko już chora przybyła, by przynajmniej w ten sposób złożyć hołd pamięci jednego ze swych nauczycieli”31.

${ }^{26}$ Wanda Nowakowska, „Profesor Mieczysław Wallis”, w: Sylwetki łódzkich uczonych, 7.

27 Zob. Wallis, Materiały Archiwalne, Rps 11, t. II, 128-133.

${ }_{28}$ Por. Dudek, Problem unaukowienia etyki, 15.

29 Wallis, Materiały Archiwalne, Rps 11, t. I, 125.

${ }^{30}$ M. Ossowska zmarła 13 sierpnia 1974 roku. Por. Elżbieta Neyman, „Słowo wstępne”, w: Maria i Stanisław Ossowscy. Intymny portret uczonych, 6.

31 Wallis, Materiały Archiwalne, Rps 11, t. I, 125. 


\section{Przynależność do szkoły lwowsko-warszawskiej jako naczelny determinant $\mathrm{i}$ trwały fundament powinowactwa intelektualnego Mieczysława Wallisa i Marii Ossowskiej}

Wskazany już paralelizm postaw naukowych obojga uczonych, zarysowujący się u źródeł ich drogi akademickiej, nie jest przypadkowy. Uczonych połączyły bowiem wspólne korzenie naukowe oraz inspiracje intelektualne, które trwale wyznaczyły ważne dla nich standardy rozumienia i uprawiania nauki, a także fundamenty aksjologiczne postawy uczonego, o których realizację nieustępliwie zabiegali. Okres ich studiów akademickich na Uniwersytecie Warszawskim przypadał bowiem na lata wzmożonej aktywności czołowych uczniów Kazimierza Twardowskiego, fundatora filozoficznej szkoły lwowsko-warszawskiej, przede wszystkim wspomnianego już Jana Łukasiewicza i Tadeusza Kotarbińskiego. Jedną z naczelnych dyrektyw szkoły był zaś postulat unaukowienia wszystkich dyscyplin filozoficznych. Jak zaznacza Witold Mackiewicz, według Twardowskiego:

Zadaniem filozofii naukowej jest przeciwstawianie się jałowej spekulacji, którą jest zabieganie o coraz bardziej doskonałą precyzję pojęć, docieranie do znaczenia wykorzystywanych terminów, ścisłego konstruowania myśli i usuwanie nieporozumień słownych powstałych wskutek ich wieloznaczności ${ }^{32}$.

Stąd też uczony dążył do wprowadzenia na grunt dyscyplin filozoficznych metodologii zrywającej z aprioryzmem, irracjonalizmem, metafizycyzmem, ugruntowanej w materiale o charakterze empirycznym, wykorzystującej narzędzia logiki, stawiającej na analizę (pojęciową, terminologiczną i semantyczną), dbającą o jasność i klarowności wywodu.

Program naukowy swego mistrza przejął z czasem także Tadeusz Kotarbiński i starał się konsekwentnie zaszczepiać go kolejnym pokoleniom młodych intelektualistów. Na III Zjeździe Filozoficznym w 1936 roku, w Krakowie,

32 Witold Mackiewicz, „Szkoły i orientacje filozoficzne”, w: Polska filozofia powojenna, red. Witold Mackiewicz (Warszawa: Witmark, 2001), 42. 
gdzie obecni byli zarówno Wallis, jak i Ossowska (i zapewne mieli też możliwość wysłuchania prelekcji swego mistrza), Tadeusz Kotarbiński za jedno z naczelnych zadań stojących przed ówczesnymi filozofami uznał usunięcie z dociekań filozoficznych zagadnień niedostatecznie poprawnie sformułowanych. Głosił:

Żywotnym zadaniem dla zawodowych filozofów jest w końcu likwidacja zagadnień źle postawionych i złudnych prób odpowiadania na nie, od których roją się dzieje spekulacji, uprawianych pod znakiem filozofii ${ }^{33}$.

Młodzi adepci filozofii mieli zatem niezwykłą sposobność wzrastania w specyficznej atmosferze intelektualnej „szkoły rzetelnego myślenia” i możliwość przesiąknięcia jej ideałami. Stąd też zasadnie zaliczani są oni do II generacji szkoły lwowsko-warszawskiej ${ }^{34}$. Co ważne, kontakt intelektualny z warszawskimi reprezentantami szkoły zadecydował nie tylko o przyświecających im ideałach naukowych, ale także wpłynął na ich dalsze naukowe wybory i postawy. To bowiem warszawscy profesorowie wskazywali im, że umiłowanie przedmiotu twórczego wysiłku człowieka daje najpiękniejsze i najwartościowsze intelektualnie owoce. To oni także rozbudzali intelektualne predylekcje młodych miłośników nauki, rozwijali ich kreatywność, a ostatecznie wyposażyli w umiejętności niezbędne do prowadzenia samodzielnej pracy badawczej. Zaszczepili im także przekonanie o potrzebie unaukowienia dyscyplin filozoficznych i wiarę w takie postulaty, jak: racjonalizm, wiarygodność i potrzeba umocowania głoszonych tez w sferze faktów (empiryzm metodologiczny), kult jasności i ścisłości wypowiedzi, dokładność, dociekliwość, precyzja terminologiczna, wyraźne definiowanie pojęć i skrupulatne uzasadnianie twierdzeń ${ }^{35}$. Pisał o tym zresztą sam Wallis we wstępie do jednego ze swych dzieł, głosząc następująco:

33 Tadeusz Kotarbiński, „Żywotne i mniej żywotne koncepcje zadań filozofii”, Przegląd Filozoficzny 2 (1936): 366.

${ }_{34}$ Por. Jan Woleński, Filozoficzna szkoła lwowsko-warszawska (Warszawa: PWN, 1985), 299-300.

35 Por. Jan Skoczyński, Jan Woleński, Historia filozofii polskiej (Kraków: Wyd. WAM, 2010), 440-441. 
Moim mistrzom warszawskim w dziedzinie filozofii, Janowi Łukasiewiczowi i Tadeuszowi Kotarbińskiemu oraz ich lwowskiemu nauczycielowi, Kazimierzowi Twardowskiemu, zawdzięczam dążenie do precyzyjnego rozróżniania i definiowania terminów, do największej poprawności w rozumowaniu, do możliwie najjaśniejszego formułowania myśli ${ }^{36}$.

Z kolei w przypadku Marii Ossowskiej wpływ uczniów Kazimierza Twardowskiego na jej postawę naukową podkreśla wielu współczesnych badaczy jej sylwetki twórczej. Należy do nich m.in. Joanna Rutkowska-Hajduk, która pisze, co następuje:

W ślad za swoimi nauczycielami z okresu studiów twierdziła, że w filozofii trzeba zrezygnować $\mathrm{z}$ rozumowań prowadzonych $\mathrm{w}$ sposób nieścisły i wieloznaczny; postulowała stosowanie $\mathrm{w}$ badaniach metody opisu analitycznego oraz proponowała odejście od zagadnień, których nie można jednoznacznie opracować37.

Zarówno Ossowska, jak i Wallis swe rozprawy doktorskie finalizowali pod opieką naukową Łukasiewicza. Nie ulega jednak wątpliwości, że ich najważniejszym naukowym mentorem był autor koncepcji „etyki niezależnej”38. O uznaniu, jakim Ossowska darzyła Kotarbińskiego, pisał m.in. Klemens Szaniawski:

Promotorem jej rozprawy doktorskiej, poświęconej etyce stoików, był znakomity logik i filozof, Jan Łukasiewicz. Z wdzięcznością wspominała Ossowska jego opiekę naukową, rygorystyczne wymagania, a zarazem sumienność posuwającą się aż do sprawdzenia wszystkich cytatów (w języku greckim oczywiście). Nie ulega jednak wątpliwości [...], że jej nauczycielem w najgłębszym sensie tego słowa był Tadeusz Kotarbiński. Głoszony przez niego w pierwszych wykładach na Uniwersytecie Warszawskim program „małej filozofii” uznała za własny. Chodziło o nieefektowny, lecz niezbędny trud dociekań pojęciowych,

${ }^{36}$ Mieczysław Wallis, Przeżycie i wartość: pisma z estetyki nauki o sztuce 1931-1949 (Kraków: Wyd. Literackie, 1968), 25.

37 Joanna Rutkowska-Hajduk, „Ossowska M.”, Polskie Towarzystwo Tomasza z Akwinu, https://docplayer.pl/6448730-Ossowska-m-pef-copyright-by-polskie-towarzystwo-tomaszaz-akwinu.html, dostęp: 01.06.2019.

38 Wallis, Materiały Archiwalne, Rps 11, t. II, 132. Por. także Krzysztof Kiciński, „Posłowie”, w: Maria Ossowska, O człowieku, moralności i nauce, 562. 
zmierzający do nadania zagadnieniom filozoficznym takiej postaci, by można było odpowiedzialnie podjąć próbę ich rozstrzygnięcia ${ }^{39}$.

Z kolei o Wallisowskim stosunku do autora Traktatu o dobrej robocie świadczą jednoznacznie jego własne zapiski. Wskazują one, że Kotarbiński budził jego najwyższy podziw, w każdej sferze życia stanowiąc dlań autorytet (nauczycielski, duchowy, intelektualny, moralny, naukowy). Wallis widział w nim zatem charyzmatycznego, intelektualnego przewodnika o mocnym kręgosłupie moralnym, bezkompromisowego w wyznawanych poglądach, ale zarazem także pełnego tolerancji dla odmienności przekonań i postaw ludzkich, życzliwego i skorego do pomocy innym. Stąd też nie dziwią Wallisowskie wypowiedzi, w których pisał o swym mistrzu następująco: „Człowiek - sztandar, człowiek - symbol, rycerz bez trwogi i bez skazy, Książę niezłomny naszych czasów” ${ }^{40}$. Jak też: „Ze wszystkich ludzi, z którymi zetknąłem się w życiu, T.K. ${ }^{41}$ wydaje mi się najbliższym doskonałości”"22. Zarówno Wallis, jak i Ossowska nie tylko niezwykle poważali nauczycielski i życiowy autorytet Kotarbińskiego, ale także przejęli odeń wiele dyrektyw naukowych, szczególnie metodologicznych, dotyczących sposobu uprawiania nauki, formułowania głoszonych twierdzeń, zwłaszcza w kontekście metodologicznego krytycyzmu, ścisłości i precyzji terminologicznej, dążąc tą drogą do usuwania wieloznaczności jako częstej przyczyny pozornych problemów filozoficznych.

Zarówno Wallisowi, jak i Ossowskiej przyświecały także ważne i pieczołowicie rozbudzane przez ich mistrza dyrektywy aksjologiczne, cenne dla postawy uczonego, tj.: uczciwość, życzliwość, poszanowanie godności ludzkiej, tolerancja, honorowość, niezłomność charakteru, bezkompromisowość, hart ducha, ambicja, wiara we własne przekonania, odwaga cywilna, bycie pomocnym dla innych, odpowiedzialność, słowność, systematyczność, punktualność, sumienność, pracowitość, obowiązkowość, precyzja czynu i słowa ${ }^{43}$.

39 Wallis, Materiały Archiwalne, Rps 11, t. II, 132.

40 Tamże, Rps 14, t. I-III, 9.

${ }^{41}$ Skrót dotyczy nazwiska „Tadeusz Kotarbiński”.

42 Tamże, t. I, 10.

${ }^{43}$ Szerzej na ten temat zob.: Joanna Zegzuła-Nowak, „Wzorzec postawy naukowej w założeniach programowych szkoły lwowsko-warszawskiej”, w: Filozofia jako mądrość bycia. 
Tymi wartościami oboje kierowali się w swym życiu zawodowym i prywatnym. W ich postawach widoczne są także inspiracje wzorem etycznym opiekuna spolegliwego, stanowiącego fundament koncepcji etycznej Tadeusza Kotarbińskiego. Wśród jego najważniejszych atrybutów znajdowały się bowiem takie cechy, jak: życzliwość, prawość, wrażliwość na cudze cierpienie, odpowiedzialność, gotowość do pomocy, nieuleganie pokusom i emocjom. Jak przekonywał sam uczony:

istotne etycznie zachowanie się jest właściwe postawie spolegliwego opiekuna, czyli człowieka, na którym można polegać w trudnych okolicznościach, człowieka, który okaże dobre serce i nie porzuci posterunku, na którym sprawuje obronę, ani ze strachu, ani ulegając podszeptowi przekupstwa, ani zwiedziony powabem pokusy ${ }^{44}$.

Jak pokazuje biografia intelektualna Marii Ossowskiej, była ona uczoną, której w wielu przedsięwzięciach przyświecały właśnie te dyrektywy. Jej drogę naukowo-życiową bez reszty wypełniała troska o realizację wartości i cnót w jej przekonaniu fundamentalnych dla ludzkości, tj.: uczynności, życzliwości, godności, autonomii myśli i czynów, męstwa, prawdy, szczerości, prawości czy też tak bliskiego Wallisowi piękna ${ }^{45}$. W ich urzeczywistnianiu widziała ona najgłębszy sens pracy uczonego, nie tylko na niwie nauki, ale także w dziedzinie jego wkładu w życie społeczne. Wartości te ceniła jako nieodłączny fundament afirmowanej przez siebie postawy obywatelskiej ${ }^{46}$, którą

Profesorowi Krzysztofowi Kaszyńskiemu w darze z okazji 70. urodzin, red. Stefan Konstańczak i in. (Zielona Góra: Oficyna Wydawnicza Uniwersytetu Zielonogórskiego, 2009), 45-52.

44 Tadeusz Kotarbiński, „Jak i dlaczego powstała etyka niezależna z wzorcem naczelnym spolegliwego opiekuna?", w: tenże, Pisma etyczne (Wrocław-Warszawa-Kraków-Gdańsk-Łódź: Ossolineum, 1987), 194.

45 O zadaniach uczonego i jego społecznej misji Ossowska mówiła następująco: „potrzebni są nam ludzie o mocnym kręgosłupie, który nie zachwieje się wraz z każdą zmianą wiatru. Decyduje o nim posiadanie hierarchii wartości, do której jest się przywiązanym i z której nie zamierza się rezygnować. Uparta obrona tych wartości stanowi o postawie, którą nazywamy godnością. Potrzebni są nam ludzie wrażliwi na krzywdę i niezasłużone przywileje, ludzie, którzy spieszą innym z pomocą i nie odwracają się od przyjaciół, gdy im się nie powiedzie. [...] Potrzebni są nam ludzie uczciwi wobec siebie i wobec innych, ludzie, którym się ufa”. Maria Ossowska, „Przebyta droga (rozmowa z prof. Marią Ossowską)”, w: tejże, O człowieku, moralności i nauce, 559.

46 Por. Zegzuła-Nowak, „Wzorzec postawy naukowej”, 169. 
można według niej rozwijać tylko w ustroju demokratycznym, „w którym nie ma uciskających i uciskanych, uprzywilejowanych i upośledzonych, [...] w którym w atmosferze swobody każdy rozwinąć może swoje zdolności” ${ }^{47}$.

Uczona z niezwykłym zaangażowaniem oddawała się działaniom na rzecz obrony wyznawanych wartości, nie tylko jako naukowiec i dydaktyk, ale także społecznik. Naznaczona doświadczeniem zdobytym podczas lat okupacji i wojny przekonywała, że ludzkości potrzeba przede wszystkim uniwersalnych wzorów i wartości moralnych, które mogłyby stanowić fundamentalne ramy kształtujące życie każdej wspólnoty. Trudno dziś nie zgodzić się, że w każdej zbiorowości ludzkiej „pragnęłoby się widzieć dookoła siebie ludzi z głową otwartą, umysłem samodzielnym i krytycznym, odwagą w obronie poglądów uważanych przez się za słuszne"48. Takim wzorem uczonej, nauczyciela akademickiego i po prostu człowieka była sama Ossowska - na niwie pracy akademickiej, naukowej, publicznej, jak również w życiu prywatnym. Swą postawą życiowo-naukową wskazywała bowiem, że warto, a nawet trzeba walczyć o dobro wspólne, sprawiedliwość, równość i wolność w każdej sferze aktywności ludzkiej ${ }^{49}$. Stąd też żywiołowo piętnowała wszelkie przejawy ludzkiego zniewolenia i dyskryminacji ${ }^{50}$.

W tym kontekście na szczególne uznanie zasługuje jej wieloletnia, niestrudzona pomoc niesiona ofiarom represji ideologiczno-politycznych, która stanowi przykład realizacji idei dzielnego opiekuństwa. W czasie II wojny światowej Ossowska wraz z mężem prowadziła tajne nauczanie, a wspierając Radę Pomocy Żydom, czynnie działała na rzecz prześladowanej ludności pochodzenia semickiego. Później zaś, w okresie powojennym, wytrwale stawała w obronie represjonowanych za działalność opozycyjną młodych studentów,

${ }^{47}$ Maria Ossowska, Wzór demokraty. Cnoty $i$ wartości (Lublin: Instytut Wydawniczy Daimonion, 1992), 14-15. Zob. także Włodzimierz Tyburski, „Maria Ossowska o powinnościach obywatelskich w ustroju demokratycznym”, w: W kręgu twórczości Marii Ossowskiej, 145-146.

48 Maria Ossowska, „Szkic autobiograficzny”, 544. Uczona ujęciu cech uniwersalnych, pożądanych i wartościowych dla każdej zbiorowości ludzkiej poświęciła dzieło pt. Wzór obywatela $w$ ustroju demokratycznym.

49 Por. Zegzuła-Nowak, „Wzorzec postawy naukowej”, 168-169.

${ }^{50}$ Joanna Zegzuła-Nowak, „Wzorzec człowieka nauki w założeniach programowych i postawach naukowych Marii i Stanisława Ossowskich”, w: W kręgu twórczości Marii Ossowskiej, 167-173. 
a także przeciwstawiała się ograniczaniu wolności słowa w nauce. Co ważne, wszelkie działania pomocowe, które mogły narażać ją na niebezpieczeństwo, zawsze traktowała jako normalną ludzką powinność ${ }^{11}$. Stąd nie ustawała w swej pracy dydaktycznej także w rzeczywistości wojennej, rzetelnie pełniąc swą nauczycielską misję. Co ciekawe, w archiwaliach Wallisa znajduje się interesujące wspomnienie pośmiertne Klemensa Szaniawskiego, który tak oto pisał o działalności społecznej swej wykładowczyni oraz jej męża: „Ossowska należała do rzadkich niestety ludzi, którzy czują się współodpowiedzialni za moralny kształt życia publicznego”. A dalej: „W latach wojny oboje Ossowscy należeli do najaktywniejszych wykładowców konspiracyjnego Uniwersytetu Warszawskiego. Zajęcia często odbywały się w ich żoliborskim mieszkaniu. [...] Z zajęć tych zrodziły się Podstawy nauki o moralności”52.

Podobną postawą cechował się także Mieczysław Wallis. Jak podkreśla jego uczennica Wanda Nowakowska, „walka o „słuszną sprawę oznaczała także w życiu Profesora określoną postawę Polaka-patrioty”53. Poczucie odpowiedzialności i odwagi cywilnej na niwie życia społecznego realizował on zatem, aktywnie działając na rzecz obrony ojczyzny. Był nie tylko uczestnikiem Legii Akademickiej, ale także wojny bolszewickiej w 1920 roku. „Brał udział w walkach o Warszawę, Zamość, Hrubieszów, za co otrzymał Medal Niepodległości [...]" ${ }^{54}$. Ponadto uczestniczył także w II wojnie światowej jako dowódca plutonu obrony przeciwlotniczej; bronił też okupowanej Warszawy. Trafił wówczas do obozów niemieckich jako jeniec - najpierw do Osterode, następnie Woldenberga, gdzie spędził łącznie prawie pięć lat. Co ważne, nie zaprzestał wówczas swej pracy naukowo-dydaktycznej. To z tego okresu pochodzą jego niezwykle intrygujące poznawczo, niepublikowane dotąd „rozmyślania filozoficzne” pt. „Skróty”, w których z niezwykłą przenikliwością i dojrzałością snuje refleksje m.in. z zakresu problematyki moralnej (tzw. mo-

51 Por. Kiciński, „Posłowie”, 563-564. Więcej o działalności Ossowskiej w imię wyznawanych wartości piszę w artykule „Wzorzec postawy naukowej w założeniach programowych szkoły lwowsko-warszawskiej", 165-180.

${ }_{52}$ Wallis, Materiały Archiwalne, Rps 11, t. II, 132. Źródło to stanowi wycinek prasowy wspomnienia pośmiertnego Klemensa Szaniawskiego pt. „Poznanie i troska o wartości”, zamieszczonego w gazecie Literatura 34 (1974).

53 Nowakowska, „Profesor Mieczysław Wallis”, 8.

54 Tamże. 
ralia), antropologii filozoficznej, aksjologii oraz estetyki ${ }^{55}$. Warto podkreślić, że w ramach działalności oświatowej Wallis prowadził w obozach wykłady $\mathrm{z}$ historii filozofii oraz historii sztuki ${ }^{56}$, i jak zaznaczają jego uczniowie, jako człowiek i nauczyciel był zawsze lojalny wobec ludzi, niezwykle życzliwy, a przy tym skromny i oddany pracy naukowej ${ }^{57}$. Pozostawił po sobie grono intelektualnych następców; po jego śmierci jeden z nich pisał o nim następująco: „ci, którzy znali Mieczysława Wallisa, będą pamiętali [...] człowieka wyjątkowej dobroci, szlachetnego, nieustępliwie uczciwego" 58 .

Mimo wspólnych zajęć i inicjatyw w środowisku akademickim oboje uczeni po zakończeniu edukacji akademickiej wybrali odmienne ścieżki naukowej samorealizacji. Choć mieli różne zainteresowania naukowo-badawcze, wspólne pozostało im zaszczepione przez uczonych ze szkoły lwowsko-warszawskiej specyficzne podejście do pracy naukowej. Cechowało ich bowiem niezwykłe zacięcie naukowo-badawcze, perfekcjonizm twórczy, unikanie intelektualnej rutyny i stagnacji. Oprócz tego łączyły ich zrodzone we wczesnej młodości intelektualnej, głębokie i stałe umiłowanie przedmiotu swych dociekań oraz ich aksjologiczne zorientowanie (odpowiednio: etyczne - Ossowska i estetyczne - Wallis). Autor dzieła Przeżycie i wartość całe swe życie poświęcił próbie wyjaśnienia i adekwatnego ujęcia istoty zjawisk oraz kategorii estetycznych, przede wszystkim wartości i przeżyć estetycznych, w których upatrywał źródeł wykraczającego poza prozę życia ludzkiego ukontentowania. Był on wielkim miłośnikiem sztuki, cechowała go ogromna wrażliwość na różnorodne przejawy wartości estetycznych i ich artystyczny wyraz. Jak pisał o nim jego uczeń, Jan Białostocki, intelektualista ten „żył przede wszystkim w świecie myśli i kultury, i świat ten swoją myślą pomnażał. [...] tym, co interesowało go najbardziej, tym, co go prawdziwie obchodziło,

55 Jak zaznaczał sam Wallis, zapiski te pochodzą z lat 1942-1944. Zob. Wallis, Materiały Archiwalne, teczka Rps 19, t. III-V, 160.

56 Por. tenże, Materiały Archiwalne, Zbiory Specjalne Instytutu Sztuki Polskiej Akademii Nauk, nr inw. 1599/I, 3; Nowakowska, „Profesor Mieczysław Wallis”, 9.

57 Tejże, „Profesor Mieczysław Wallis”, 9.

58 Jan Białostocki, „Wspomnienie pośmiertne. Mieczysław Wallis 1875-1975 (Przemówienie wygłoszone nad grobem w dniu 30 października 1975 r.)", w: Mieczysław Wallis, Sztuki i znaki. Pisma semiotyczne (Warszawa: PIW, 1983), 339. 
była sztuka i stosunek człowieka do sztuki" ${ }^{59}$. Jego dociekania filozoficzne doprowadziły go do wniosku, że tym, co wyróżnia człowieka w świecie, jest fakt, iż wobec otaczającej rzeczywistości jedynie on ma zdolność przyjęcia swoistej postawy, którą można nazwać twórczo-interpretacyjną. To właśnie ona umożliwia człowiekowi poznanie bogactwa i uroku świata, a ostatecznie daje sposobność dotarcia do świata wartości. Jedynie człowiek może być czuły na wartości (szczególnie estetyczne) wkomponowane w jego otoczenie i czerpać bezinteresowną radość z obcowania z wartościowymi przedmiotami. Stąd, wspominając swego mistrza, Białostocki nie bez przyczyny określił go jako „człowieka [...] głęboko i całkowicie oddanego wartościom, w które wierzył"60.

Z kolei działalność twórczą Ossowskiej wypełniły bez reszty badania nad istotą zjawisk z zakresu moralności. Jak zaznacza Joanna Górnicka-Kalinowska, aktywność twórcza uczonej koncentrowała się wokół klasycznych i ponadczasowych pytań oraz problemów z zakresu teorii moralności, takich jak:

Dlaczego chcemy pomagać innym? Co powoduje, że pewne rzeczy wydają się nam niesprawiedliwe, inne zaś słuszne i moralnie chwalebne? Jak wyjaśnić pewne stany wewnętrzne towarzyszące moralnym wyborom lub ocenom? Jak

59 Tamże, 335. Jak podkreślają współcześni badacze jego sylwetki twórczej, szczególnie godny uwagi jest jego wkład w zakresie teorii obiektów semiotycznych, którą zastosował w odniesieniu do teorii dzieł sztuki. Jak podkreśla Horecka: „Największą zasługę Wallisa dla polskiej semiotyki upatrujemy w stworzeniu przez niego teorii znaku ikonicznego - teorii spójnej, subtelnej, najbardziej ze wszystkich teorii znaku ikonicznego powstałych w szkole lwowsko-warszawskiej rozbudowanej. Niezwykle ważną zasługą Wallisa jest również to, że [...] zastosował ją także do badania różnorodnych przedmiotów przede wszystkim dzieł sztuki, tworząc tym samym nową dyscyplinę - semiotykę sztuki”. Aleksandra Horecka, Obiekty semiotyczne w pracach Stanisława Ossowskiego, Tadeusza Witwickiego, Mieczysława Wallisa, Leopolda Blausteina, Izydory Dąmbskiej i Janiny Kotarbińskiej (Warszawa: Polskie Towarzystwo Semiotyczne, 2013), 179.

60 Białostocki, Wspomnienie pośmiertne, 339. Jak pisał Jerzy Pelc: „Umiłowanie rzeczy pięknych było treścią życia Mieczysława Wallisa; ich analiza, opis oraz interpretacja wypełniły Jego pięćdziesięcioletnie badania naukowe w zakresie estetyki, historii sztuki, teorii sztuki i semiotyki sztuki”. Jerzy Pelc, „Wspomnienia pozgonne o Mieczysławie Wallisie i Tadeuszu Wójciku”, Studia Filozoficzne 7 (1977): 5; por. także Joanna Zegzuła-Nowak, „O estetyzacji człowieka i świata (na marginesie wypowiedzi archiwalnych Mieczysława Wallisa”, Aspekty Filozoficzno-Prozatorskie 56-61/62-65/66-68 (2018): 157-161. 
psychologicznie uzasadnić stany duchowego komfortu lub cierpienia w sytuacjach moralnych? ${ }^{61}$.

Podobnie jak Wallis autorka Podstaw nauki o moralności podporządkowała całe swoje życie, nie tylko naukowo-zawodowe, ale także prywatne, pracy badawczej (np. niestrudzenie podróżując naukowo, wykładając w ośrodkach zagranicznych, współpracując $z$ wybitnymi uczonymi czy świadomie rezygnując z macierzyństwa na rzecz naukowego rozwoju) ${ }^{62}$. Sama Ossowska o swej naukowej pasji, stanowiącej główną treść jej życia, wypowiedziała się w następujących słowach:

Praca naukowa dawała mi tyle przyjemności, że właściwie nie potrzebowałam zadawać sobie pytania o sens własnego życia, bo zawsze czułam potrzebę aktywnego uczestnictwa i uważałam się za uprzywilejowaną, że mogłam robić, to co robię ${ }^{63}$.

Co więcej, zaszczepiony obojgu uczonym przez warszawskich nauczycieli kult naukowości dyscyplin filozoficznych zaowocował ich silnym przekonaniem, że dyscypliny normatywne mogą czynić zadość wymogom naukowości i można je ugruntować metodologicznie, przede wszystkim poprzez analizę materiału empirycznego. Stąd też uważali, że odpowiednio: estetykę (Wallis) lub etykę, przede wszystkim opisową (Ossowska), można traktować jako dyscypliny zorientowane empirycznie i pozbawione zdań o charakterze wartościującym.

Wallis odrzucał absolutyzm aksjologiczny ${ }^{64}$ oraz wszelkie formy estetyki zorientowanej apriorycznie (np. zdecydowanie negując fenomenologiczne

61 Joanna Górnicka-Kalinowska, „Maria Ossowska jako psycholog moralności”, w: W kręgu twórczości Marii Ossowskiej, 15.

${ }_{62}$ Por. Dudek, Problem unaukowienia etyki, 16-17; Intymny portret uczonych, 168.

${ }^{63}$ Ossowska, „Przebyta droga”, 559. W innej swej wypowiedzi głosiła też: „gdyby dane mi było żyć ponownie, wybrałabym ten sam zawód po raz wtóry. Myślę tutaj w pierwszym rzędzie o zawodzie pracownika naukowego w ogóle, a o tej problematyce, którą sobie upodobałam - w szczególności. Praca naukowa stanowiła zresztą dla mnie zawsze coś więcej niż zawód; stanowiła potrzebę równie imperatywną i równie elementarną jak głód i pragnienie”. Tejże, „O pojęciu godności”, 514.

${ }^{64}$ Negując ujęcie estetyki jako dyscypliny wartościującej, głosił, że w estetyce naukowej nie ma miejsca dla zdań o charakterze normatywnym. Argumentował bowiem, że wszystkie 
ujęcie Ingardena $)^{65}$. Był przekonany, że estetyka nie może być dyscypliną zogniskowaną wokół jakichś idealnych, obiektywnych i bezwzględnych tworów estetycznych, ale powinna być nauką empiryczną (wolną od pierwiastków irracjonalnych, spekulatywnych i metafizycznych), skupioną wokół kategorii i zjawisk estetycznych, których wyraz możemy znaleźć w otaczającym nas świecie i stąd też poddać je analizie ${ }^{66}$.

Z kolei naczelnym celem naukowej pracy Ossowskiej było „bezstronne i wszechstronne badanie zjawisk moralności”, które realizowała w oparciu o zasadę odwoływania się do bogatego i zróżnicowanego materiału faktograficznego ${ }^{67}$. Sama uczona przyświecające jej cele naukowe ujmowała następująco:

Jest to postawa beznamiętnego badacza pewnego faktycznego stanu rzeczy, postawa tego, kto bada zjawiska moralne, podobnie jak botanik bada rośliny, a językoznawca - zjawiska językowe. [...] nazywać będziemy [...] nauką o moralności dyscyplinę, która niczego w zakresie moralności nie ocenia i nie zaleca, tylko próbuje np. jak najrzetelniej zanalizować i wyjaśnić panujące w danym środowisku oceny moralne i obowiązujące w nim normy, próbuje dociec motywów, które pchają ludzi zarówno do chwalonego, jak i do ganionego w danym środowisku postępowania. [...] $]^{68}$.

Obojga intelektualistów łączyła także niezwykle twórcza, pełna pasji i oddania praca na gruncie akademicko-organizacyjnym. Przez kilka lat przynależeli oni do tej samej jednostki akademickiej, mając sposobność

zdania i sądy naukowe powinny podlegać weryfikacji (być ujęte w kategoriach prawdy i fałszu). Natomiast zdania i sądy o charakterze normatywnym nie spełniają tego wymogu. Por. Wallis, Przeżycie i wartość, 11.

65 Por. tenże, „Polemika z Ingardenem”, w: tenże, Wybór pism estetycznych (Kraków: Universitas, 2004), 223-230; zob. także Teresa Pękala, „Czy istnieje polski model uprawiania estetyki?: o estetyce Mieczysława Wallisa”, Sztuka i Filozofia 11 (1996): 176-190.

${ }^{66}$ Wallis wyjaśniał następująco: „Punktem wyjścia wszelkich rozważań estetycznych jest, jak mi się zdaje, pewien fakt niewątpliwy - istnienie przedmiotów, które w odpowiednich warunkach mogą wywoływać w odbiorcy pewne swoiste przeżycia, dla których utarła się nazwa «przeżyć estetycznych». Przeżycia estetyczne możemy wskazać, możemy je w pewien sposób opisać. Nie możemy ich zdefiniować". Wallis, Przeżycie i wartość, 8.

${ }^{67}$ Por. Dudek, Problem unaukowienia etyki, 100, 101.

68 Maria Ossowska, Podstawy nauki o moralności (Warszawa: Spółdzielnia Wydawnicza „Czytelnik”, 1947), 1. 
prowadzenia pracy dydaktycznej i chłonięcia atmosfery akademickiej na nowo powstałym Uniwersytecie Łódzkim, gdzie trafili w 1945 roku na zaproszenie swego naukowego mentora, Tadeusza Kotarbińskiego, który pełnił tam wówczas funkcję rektora. Wallis na Uniwersytecie Łódzkim pracował przez dwadzieścia lat, aż do przejścia na emeryturę. Z kolei Ossowska spędziła tam jedynie trzy lata i w 1948 roku powróciła na Uniwersytet Warszawski (gdzie jej katedra znalazła się w Sekcji Socjologicznej Wydziału Filozoficznego ${ }^{69}$. Choć Ossowska zniknęła wówczas z bezpośredniego otoczenia akademickiego Wallisa, uczony nie tracił jej z oczu, korespondując z nią czy uczestnicząc $\mathrm{w}$ uroczystościach środowiska naukowego, $\mathrm{z}$ którego oboje się wywodzili.

Co ważne, oboje także zasłużyli się dla rodzimej nauki pionierskimi dokonaniami w swej pracy akademickiej. Wallis, który początkowo objął Katedrę Estetyki, „razem z profesorem Wacławem Husarskim [...] stworzył kierunek historii sztuki, kształtując tym samym środowisko przyszłych badaczy, pracowników naukowych, muzealników, konserwatorów [...]"70. Natomiast specjalnie dla Ossowskiej utworzono wówczas pierwszą w kraju Katedrę Teorii Moralności ${ }^{71}$. Byli oni także uczestnikami wielu inicjatyw rodzimego środowiska naukowego, np. brali udział we wspomnianym już III Zjeździe Filozoficznym w Krakowie w 1936 roku $^{72}$ czy I Kongresie Nauki Polskiej w roku 1951, sprawując pieczę nad podsekcjami filozoficznymi (Ossowska jako referentka podsekcji „Nauka o moralności”, a Wallis jako referent podsekcji „Estetyka” ${ }^{73}$. Razem występowali także, głosząc swe poglądy naukowe na forum

${ }^{69}$ Por. tejże, Szkic autobiograficzny, 539; zob. także Dudek, Problem unaukowienia etyki, 13.

${ }^{70}$ Okres łódzki był czasem najbardziej płodnym zarówno naukowo, jak i dydaktycznie w życiu Wallisa. Por. Nowakowska, „Profesor Mieczysław Wallis”, 11.

${ }_{71}$ Por. Dudek, Problem unaukowienia etyki, 13.

72 Wygłosili wówczas następujące referaty: M. Ossowska - Ocena i opis (sekcja socjologii i etyki), Wallis - O właściwych i niewłaściwych przeżyciach estetycznych (sekcja estetyki). Por. Polskie zjazdy filozoficzne, red. Ryszard Jadczak (Toruń: UMK, 1995), 69, 125, 126; Skoczyński, Woleński, Historia filozofii polskiej, 399.

${ }_{73}$ Por. Radosław Kuliniak i in., Filozofia po ciemnej stronie mocy. Krucjaty marksistów i komunistów polskich przeciwko Lwowskiej Szkole Filozoficznej Kazimierza Twardowskiego. Część I: lata 1945-1951 (Kęty: Marek Derewiecki, 2018), 264-265; por. także Stefan Konstańczak, „Retoryka dominacji - polityczne sterowanie nauką”, Zagadnienia Naukoznawstwa 2 (XLIX) 2013: 110-111. 
naukowym o zasięgu międzynarodowym, np. biorąc udział w X Międzynarodowym Kongresie Filozoficznym w Amsterdamie w 1948 roku $^{74}$. Oboje też współtworzyli pierwsze polskie obcojęzyczne czasopismo filozoficzne „Studia Philosophica" (Wallis jako autor, Ossowska jako autorka i współredaktorka) $)^{75}$.

Pomimo różnych kolei losów, doświadczeń życiowych i odmienności naukowych zainteresowań oraz prac badawczych przez lata pozostała żywa nawiązana pomiędzy nimi w młodości nić intelektualnego porozumienia. Towarzyszące im poczucie wspólnej afiliacji intelektualnej demonstrowali i potwierdzali wielokrotnie, nie tylko w ramach głoszonych poglądów, postulatów metodologicznych czy uznawanego etosu pracy naukowej, ale także wielu różnych inicjatyw bliskiego im środowiska naukowego, np. tych dedykowanych ich naczelnemu intelektualnemu mentorowi, Tadeuszowi Kotarbińskiemu ${ }^{76}$. Oboje spotykali się z nim, inicjując chociażby tzw. herbatki koleżeńskie, zapraszając swego mistrza na liczne odczyty i referaty gościnne czy uczestnicząc w obchodach jubileuszów jego pracy naukowo-dydaktycznej ${ }^{77}$. Razem oddali mu także hołd jako swemu największemu Mistrzowi udziałem w Księdze pamiątkowej ku uczczeniu czterdziestolecia pracy nauczycielskiej w Uniwersytecie Warszawskim Profesora Kotarbińskiego w 1959 roku $^{78}$.

${ }^{74}$ Ossowska wygłosiła wówczas przemówienie pt. Qu’est-ce qu’un jugement de valeur?; z kolei referat Wallisa zatytułowany był następująco: On Some Casus in which Investigation Alters the Object Investigated. Por. „Bibliografia prac M. Ossowskiej”, oprac. Maria Smoła, w: Maria Ossowska, O człowieku, moralności i nauce, 596; Wanda Nowakowska, „Bibliografia prac prof. Mieczysława Wallisa", w: Sylwetki łódzkich uczonych, 54.

75 Por. Korespondencja Romana Witolda Ingardena. Z dziejów „Studia Philosophica. Commentarii Societatis Philosophicae Polonorum”, red. Radosław Kuliniak i in. (Kęty: Marek Derewiecki, 2018), 53, 66, 157.

76 Por. Zegzuła-Nowak, „Tadeusz Kotarbiński w świetle nieznanych źródeł”, 211-212.

77 Co ciekawe, Wallis podkreślał w swych zapiskach archiwalnych, że swego mistrza poznał na początku swych studiów warszawskich w 1916 roku właśnie „u państwa Niedźwieckich, rodziców koleżanki Marii Niedźwieckiej (późniejszej Ossowskiej)”. Por. Wallis, Materiały Archiwalne, Rps 14, t. I-IV, 141, 143, 144, 148.

78 Wallis opublikował tam artykuł pt. Koncepcje biologiczne w humanistyce, a Ossowska tekst pt. Norma prawna i norma moralna u Petrażyckiego. Zob. Ksiega Pamiątkowa ku uczczeniu czterdziestolecia pracy nauczycielskiej w Uniwersytecie Warszawskim Profesora Tadeusza Kotarbińskiego (Warszawa: PWN, 1959), 75-85, 307-330. 
Biografie intelektualne Marii Ossowskiej i Mieczysława Wallisa pozwalają przyjąć tezę, że wspólne dziedzictwo intelektualne stało się jednym z najistotniejszych ogniw, które trwale połączyło uczonych. To właśnie afirmacja wspólnych ideowych przekonań co do sposobu uprawiania nauki i wartości jej przyświecających wytworzyła w obojgu poczucie przynależności do naukowego kręgu, a także stała się źródłem ich trwałego intelektualnego braterstwa, mimo iż uczeni często pozostawali w oddaleniu od siebie. Ich nić intelektualnego porozumienia może stanowić w dziejach rodzimej humanistyki przykład relacji pokazującej, że uprawianie nauki nie musi być areną, na której konkurencja myśli, postaw i koncepcji prowadzi jedynie do wzajemnej ignorancji, izolacji, antagonizmów czy niechęci. Swym przykładem uczeni ci ukazują bowiem, że ludzie w swych naukowych pasjach i osiągnięciach mogą się różnić pięknie, inspirująco, a podstawą ich wzajemnego uznania i szacunku mogą być uniwersalne fundamenty aksjologiczne, bez których uprawianie nauki staje się aktywnością martwą, bo pozbawioną tego, co najważniejsze - dbałości o wzajemny szacunek, zachowanie ludzkiej godności, poczucia wspólnego dążenia do szczęścia i hołdowania wartościom stanowiącym o naszym człowieczeństwie. Jak zaznaczał bowiem w swych rękopisach Wallis, aktywność twórcza stanowi źródło nie tylko ludzkiej autokreacji, ale także daje człowiekowi poczucie doniosłości jego dokonań w perspektywie ogólnoludzkiej. Jej istotą jest „poczucie własnej mocy, wydobywającej nowe byty z nicości; zadowolenie z doskonałości nowego tworu; duma z tego, że się wzbogaciło świat; szczęście z uszczęśliwienia innych: wszystko to współdźwięczy w radości tworzenia"79. Czy może być zatem coś cenniejszego aniżeli świadomość, że przeżycia te można dzielić z kimś, dla kogo pasja twórcza jest równie ważna? Tym samym: czy w świecie nauki niemożliwe jest niezawistne braterstwo myśli i przeżyć, szczera, przyjacielska relacja, wzbogacająca wewnętrzny świat uczonych? Jak przekonywał już Arystoteles, przyjaźń stanowi siłę napędową najcenniejszych ludzkich inicjatyw:

79 Wallis, Materiały Archiwalne, Rps 19, t. III-V, 178. 
Przyjaźń dopomaga młodzieńcom do unikania błędów, starszych otacza opieką i uzupełnia ich pracę $\mathrm{w}$ tym, co przerasta ich nadwątlone siły, ludzi w kwiecie wieku pobudza do pięknych czynów. I do myślenia bowiem, i do działania zdatniejsi [są ludzie we dwójkę] ${ }^{80}$.

Warto zatem cenić każde, nawet najmniejsze zalążki przyjaźni, dbać o nie i rozwijać je niestrudzenie, także i na niwie świata nauki.

\section{Bibliografia}

Arystoteles. 1982. Etyka nikomachejska. Warszawa: PWN.

Białostocki Jan. 1983. „Wspomnienie pośmiertne. Mieczysław Wallis 1875-1975 (Przemówienie wygłoszone nad grobem w dniu 30 października 1975 r.)". W: Mieczysław Wallis, Sztuki i znaki. Pisma semiotyczne, 335-339. Warszawa: PIW.

Dudek Joanna. 2012. Problem unaukowienia etyki. Teoretyczne i normatywne aspekty twórczości Marii Ossowskiej. Zielona Góra: Oficyna Wydawnicza Uniwersytetu Zielonogórskiego.

Górnicka-Kalinowska Joanna. 2018. „Maria Ossowska jako psycholog moralności". W: W kręu twórczości Marii Ossowskiej: analiza - inspiracje - alternatywy, red. Joanna Dudek, Tomasz Turowski, Paweł Walczak, Joanna Zegzuła-Nowak, 11-22. Zielona Góra: Oficyna Wydawnicza Uniwersytetu Zielonogórskiego.

Horecka Aleksandra. 2013. Obiekty semiotyczne w pracach Stanisława Ossowskiego, Tadeusza Witwickiego, Mieczysława Wallisa, Leopolda Blausteina, Izydory Dąmbskiej i Janiny Kotarbińskiej. Warszawa: Polskie Towarzystwo Semiotyczne. Kiciński Krzysztof. 1983. „Posłowie”. W: Maria Ossowska. O człowieku, moralności i nauce. Miscellanea, 560-587. Warszawa: PWN.

Konstańczak Stefan. 2012. „Komentarz do wykładu habilitacyjnego Marii Ossowskiej". W: Maria Ossowska (1896-1974) w świetle nieznanych źródeł archiwalnych, 43-53. Zielona Góra: Oficyna wydawnicza Uniwersytetu Zielonogórskiego.

Konstańczak Stefan. 2013. „Retoryka dominacji - polityczne sterowanie nauką”. Zagadnienia Naukoznawstwa 2 (XLIX): 101-115.

Korespondencja Romana Witolda Ingardena. Z dziejów „Studia Philosophica. Commentarii Societatis Philosophicae Polonorum". 2018. Red. Radosław Kuliniak, Dorota Leszczyna, Mariusz Pandura, Łukasz Ratajczak. Kęty: Marek Derewecki.

80 Arystoteles, Etyka nikomachejska (Warszawa: PWN, 1982), 284-285 [ks. VIII 1. 1155a, 14-20]. 
Kotarbiński Tadeusz. 1987. „Jak i dlaczego powstała etyka niezależna z wzorcem naczelnym spolegliwego opiekuna?". W: Tadeusz Kotarbiński. Pisma etyczne, 194-195. Wrocław-Warszawa-Kraków-Gdańsk-Łódź: Ossolineum.

Kuliniak Radosław, Mariusz Pandura, Łukasz Ratajczak. 2018. Filozofia po ciemnej stronie mocy. Krucjaty marksistów i komunistów polskich przeciwko Lwowskiej Szkole Filozoficznej Kazimierza Twardowskiego. Część I: lata 1945-1951. Kęty: Marek Derewecki.

Maria i Stanisław Ossowscy. Intymny portret uczonych. Korespondencja Marii i Stanisława Ossowskich. 2002. Warszawa: Sic!

Neyman Elżbieta. 2002. „Słowo wstępne”. W: Maria i Stanisław Ossowscy. Intymny portret uczonych, 5-82. Warszawa: Sic!

Nowakowska Wanda. 2001. „Bibliografia prac prof. Mieczysława Wallisa”. W: Sylwetki łódzkich uczonych. Profesor Mieczystaw Wallis, z. 59, 19-60. Łódź: Łódzkie Towarzystwo Naukowe.

Nowakowska Wanda. 2001. „Profesor Mieczysław Wallis”. W: Sylwetki łódzkich uczonych. Profesor Mieczysław Wallis, z. 59, 7-18. Łódź: Łódzkie Towarzystwo Naukowe.

Ossowska Maria. 1931. „Słowa i myśli”. Przegląd Filozoficzny 4: 203-258.

Ossowska Maria. 1947. Podstawy nauki o moralności. Warszawa: „Czytelnik”.

Ossowska Maria. 1983. O człowieku, moralności i nauce. Miscellanea. Warszawa: PWN.

Ossowska Maria. 1983. „Przebyta droga (rozmowa z Marią Ossowską)”. W: Maria Ossowska, O człowieku, moralności i nauce. Miscellanea, 556-559. Warszawa: PWN.

Ossowska Maria. 1983. „Szkic autobiograficzny”. W: Maria Ossowska, O człowieku, moralności i nauce. Miscellanea, 538-540. Warszawa: PWN.

Ossowska Maria. 1992. Wzór demokraty. Cnoty i wartości. Lublin: Daimonion.

Pelc Jerzy. 1977. „Wspomnienia pozgonne o Mieczysławie Wallisie i Tadeuszu Wójciku”. Studia Filozoficzne 7: 5-12.

Pękala Teresa. 1996. „Czy istnieje polski model uprawiania estetyki?: o estetyce Mieczysława Wallisa". Sztuka i Filozofia 11: 69-79.

Pękala Teresa. 1997. Estetyka otwarta Mieczysława Wallisa. Warszawa: Instytut Kultury.

Pękala Teresa. 2004. „Świat jako przedmiot estetyczny. Wprowadzenie”. W: Mieczysław Wallis. Wybór pism estetycznych, X-CXIV. Kraków: Universitas.

Polskie zjazdy filozoficzne. 1995. Red. Ryszard Jadczak. Toruń: UMK.

Rutkowski Krzysztof. 2001. „Bibliografia prac Mieczysława Wallisa”. W: Sylwetki łódzkich Uczonych. Profesor Mieczysław Wallis, z. 59, 19-60. Łódź: Łódzkie Towarzystwo Naukowe.

Skoczyński Jan, Woleński Jan. 2010. Historia filozofii polskiej. Kraków: WAM. 
Tyburski Włodzimierz. 2006. Elzenberg. Warszawa: Wiedza Powszechna.

Tyburski Włodzimierz. 2018. Maria Ossowska o powinnościach obywatelskich w ustroju Demokratycznym. W: W kręgu twórczości Marii Ossowskiej: analiza inspiracje - alternatywy, red. Joanna Dudek, Tomasz Turowski, Paweł Walczak, Joanna Zegzuła-Nowak, 143-150. Zielona Góra: Oficyna Wydawnicza Uniwersytetu Zielonogórskiego.

Wallis Mieczysław. 1968. Przeżycie i wartość: pisma z estetyki nauki o sztuce 1931-1949. Kraków: Wyd. Literackie.

Wallis Mieczysław. 1983. Sztuki i znaki. Pisma semiotyczne. Warszawa: PIW.

Wallis Mieczysław. 2004. Wybór pism estetycznych. Kraków: Universitas.

Woleński Jan. 1985. Filozoficzna szkoła lwowsko-warszawska. Warszawa: PWN.

Zegzuła-Nowak Joanna. 2009. „Wzorzec postawy naukowej w założeniach programowych szkoły lwowsko-warszawskiej”. W: Filozofia jako madrość bycia. Profesorowi Krzysztofowi Kaszyńskiemu w darze z okazji 70. urodzin, red. Stefan Konstańczak, Tomasz Turowski, 45-51. Zielona Góra: Oficyna Wydawnicza Uniwersytetu Zielonogórskiego.

Zegzuła-Nowak Joanna. 2013. „Mieczysław Wallis i Henryk Elzenberg w estetyce polskiej XX wieku. Studium porównawcze". Edukacja Filozoficzna 55: 61-80.

Zegzuła-Nowak Joanna. 2015. „Tadeusz Kotarbiński w świetle nieznanych źródeł archiwalnych Mieczysława Wallisa". W: Homo moralis - homo creativus. Prace dedykowane profesorom Zdzisławowi Kalicie, Krzysztofowi Kaszyńskiemu, red. Joanna Dudek, Stefan Konstańczak, 209-230. Zielona Góra: Oficyna Wydawnicza Uniwersytetu Zielonogórskiego.

Zegzuła-Nowak Joanna. 2016. Mieczysław Wallis i Henryk Elzenberg o sztuce i moralności (na podstawie korespondencji wzajemnej). Zielona Góra: Oficyna Wydawnicza Uniwersytetu Zielonogórskiego.

Zegzuła-Nowak Joanna. 2018. „Jan Łukasiewicz jako nauczyciel, mentor i inspirator twórczej aktywności Mieczysława Wallisa”. Studia z Historii Filozofii 2: 69-90.

Zegzuła-Nowak Joanna. 2018. „O estetyzacji człowieka i świata (na marginesie wypowiedzi archiwalnych Mieczysława Wallisa)". Aspekty Filozoficzno-Prozatorskie $(56-61) /(62-65) /(66-68): 157-161$.

Zegzuła-Nowak Joanna. 2018. „Wzorzec człowieka nauki w założeniach programowych i postawach naukowych Marii i Stanisława Ossowskich". W: W kreggu twórczości Marii Ossowskiej: analiza - inspiracje - alternatywy, red. Joanna Dudek, Tomasz Turowski, Paweł Walczak, Joanna Zegzuła-Nowak, 165-180. Zielona Góra: Oficyna Wydawnicza Uniwersytetu Zielonogórskiego. 


\section{Strony internetowe}

Instytut Sztuki Polskiej Akademii Nauk, Zbiory Specjalne. Dostęp 26.01.2020. http:// www.ispan.pl/pl/zbiory/zbiory-specjalne.

Joanna Rutkowska-Hajduk, „Ossowska M.”, Polskie Towarzystwo Tomasza z Akwinu. Dostęp 01.06.2019. https://docplayer.pl/6448730-Ossowska-m-pef-copyrightby-polskie-towarzystwo-tomasza-z-akwinu.html.

Nauka Polska, wyszukiwanie dla hasła „Maria Ossowska”. Dostęp 26.01.2020. https:// nauka-polska.pl.

„Maria Ossowska 1896-1974”. Dostęp 26.01.2020. http://ossowska.isns.uw.edu.pl/ publikacje.html

\section{Archiwalia}

Mieczysław Wallis, Materiały Archiwalne. Archiwum Połączonych Bibliotek Wydziału Filozofii i Socjologii UW, Instytutu Filozofii i Socjologii PAN oraz Polskiego Towarzystwa Filozoficznego, teczki: Rps 8; Rps, 10, T. I, VI, IX; Rps 11, t. I-II; Rps 14, t. I-IV; Rps 15, t. I, Rps 16, t. I-III; Rps 19, t. III-V.

Mieczysław Wallis, Materiały Archiwalne. Zbiory Specjalne Instytutu Sztuki Polskiej Akademii Nauk, nr inw. 1599/I, k. 3.

\section{Abstract \\ Mieczysław Wallis and Maria Ossowska. Study of the Relationship on the Margins of Archival Materials}

The article presents an intellectual relationship between Mieczysław Wallis and Maria Ossowska in the light of his archival materials (memories, notes). It shows the existing scientific affinity between scholars who despite the different scientific interests (Wallis dealt with the aesthetics and theory of art, Ossowska was interested in ethics and theory of morality) were guided by common scientific directives. They had common scientific roots - they both came from the philosophical Lvov-Warsaw school. Thus, in their scientific work, such postulates as: methodological empiricism, anti-metaphysicianism, cult of accuracy and clarity of expression, terminological precision, logical justification of the theses were important to them. We meet scientists from the intellectual atmosphere of the era in which they both lived and created.

Keywords: Mieczysław Wallis, Maria Ossowska, archival materials, mutual intellectual relation, history of 20th century Polish philosophy. 


\section{Streszczenie}

\section{Mieczysław Wallis a/i Maria Ossowska. Studium relacji na marginesie materiałów archiwalnych}

Artykuł przedstawia intelektualny związek Mieczysława Wallisa z Marią Ossowską w świetle zachowanych przez filozofa materiałów archiwalnych (wspomnień, notatek). Pokazuje więź naukową istniejącą między uczonymi, którzy pomimo różnych zainteresowań badawczych (Wallis zajmował się estetyką i teorią sztuki, Ossowska interesowała się etyką i teorią moralności) kierowali się tymi samymi dyrektywami naukowymi. Wallis i Ossowska mieli wspólne naukowe korzenie - wywodzili się z filozoficznej szkoły lwowsko-warszawskiej. Stąd też w ich pracy naukowej ważne były takie postulaty, jak: empiryzm metodologiczny, antymetafizycyzm, kult dokładności i jasności wypowiedzi, precyzja terminologiczna, logiczne uzasadnienie tez. Artykuł ukazuje naukowców w intelektualnej atmosferze epoki, w której oboje żyli i tworzyli.

Słowa kluczowe: Mieczysław Wallis, Maria Ossowska, materiały archiwalne, związki intelektualne, historia polskiej filozofii XX wieku. 